Електронне наукове фахове видання «Адаптивне управління: теорія і практика. Серія «Педагогіка»

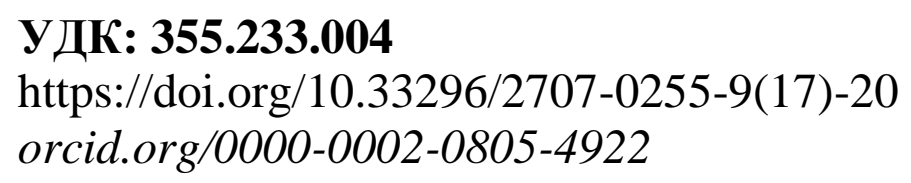

ВОЛОДИМИР ШПОРТЬКО

викладач кафедри загальновійськових

дисииплін

Украйнської військово-медичної академії

(Київ, Україна)

\title{
АНАЛІЗ РЕЗУЛЬТАТІВ ФОРМУВАЛЬНОГО ЕКСПЕРИМЕНТУ ІЗ ПЕРІВІРКИ ОРГАНІЗАЦІЙНО-ПЕДАГОГІЧНИХ УМОВ РОЗВИТКУ ПРОФЕСІЙНОЇ КУЛЬТУРИ МАЙБУТНІХ ВІЙСЬКОВИХ ЛІКАРІВ
}

Автором статті надається методика i результати проведеного експериментального дослідження стану та розвитку професійної культури майбутніх військових лікарів в системі військово-медичної освіти. Стаття висвітлює результати констатуючого, контрольного i формувального експериментів у яких прийняли участь студенти медичних університетів України, які проходили військову підготовку у медичних університетах, i слухачі Української військово-медичної академії.

Наведено аналіз останніх досліджень і публікацій вчених які розкривають суть поняття «професійна культура», висвітлено аналогічні розробки у галузі військово-медичної освіти України. Здійснюючи власну експериментальну перевірку автор спирається на теоретичні напрацювання науковців у яких розкрито методику «педагогічного експерименту». Протягом педагогічної діагностики було застосовано такі методи дослідження як незалежна експертна оцінка групою експертів, спостереження, анкетування, бесіда і інтерв’ю.

Протягом педагогічного експерименту було поставлене завдання перевірку гіпотези дослідження щодо розвитку професійної культури лікарів, шляхом створення відповідних організаційно-педагогічних умов, де автор передбачає впровадження когнітивної-направленої технології, застосування експліцитнопсихологічного впливу до студентів медиків. У даній статті автор здійснює 
Електронне наукове фахове видання «Адаптивне управління: теорія і практика. Серія «Педагогіка»

аналіз результатів етапів проведення констатуючого i формувального експерименту, що дає змогу встановити стан педагогічної системи що вивчається, реальний рівень сформованості і розвитку професійної культури студентів. За результатами експериментального дослідження виявляються причино-наслідкові зв'язки тривалості педагогічного процесу, відбувається подальша дослідницька робота що дає змогу впровадження нової педагогічної технології спрямованої на покращення результатів у навчанні і вихованні студентів медичних університетів та слухачів УВМА.

Розвиток професійної культури майбутніх військових лікарів у системі військово-медичної освіти було досліджено за допомогою таких структурних компонентів як: когнітивного, комунікативного, мотиваційно-ціннісного, морально-етичного, етнокультурного і організаційного. Висновки дослідження використані у впровадженні педагогічних технологій, дозволяють у подальшому корегувати методику процесу навчання майбутніх військових лікарів, продовжувати пошуково-експериментальну роботу 3 метою покращення форм і методів навчання студентів, набуття ними достатніх професійних навичок і вмінь.

Ключові слова: експериментальна перевірка, професійна культура, розвиток, педагогічна діагностика, організаційно-педагогічні умови, майбутні військові лікарі.

Постановка проблеми. Сучасний етап розвитку Збройних Сил України і Медичних сил України гостро потребує вдосконалення системи військовомедичної освіти, проведення дослідження щодо розвитку професійної культури науково-педагогічних працівників, студентів i слухачів вищих медичних закладів України. В умовах поглиблення євроінтеграції освітнього процесу країни, наближення системи військово-медичної освіти до євроатлантичних стандартів і досягнення якісних показників у підготовці майбутніх військових 
Електронне наукове фахове видання «Адаптивне управління: теорія і практика. Серія «Педагогіка»

лікарів виникає необхідність проведення експериментальних досліджень щодо розвитку професійної культури.

Аналіз останніх досліджень і публікацій. В контексті формування і розвитку професійної культури лікарів достатньо уваги привертають дослідження Е. Белоконева, Ю. Вороненка, О. Гури, Н. Миколаєнка, О. Мінцера, В. Краснова, О. Кульбаха, О. Парахіна. Питанням удосконалення кваліфікації викладачів військово-медичної освіти присвячені роботи Я. Радиш, А. Романенка і В. Солярика. Особливості підготовки військових лікарів в системі військово-медичної освіти і підвищення їх професійного рівня системно розкриті у працях М. Бойчака, Л. Голіка, В. Жаховського, Б. Клішевича, Ю. Румянцева.

Педагогічна діагностика та експериментальна перевірка підготовки майбутніх спеціалістів в теорії і практиці педагогіки розкрита у працях відомих педагогів С. Архангельського, Ю. Бабанського, В. Журавльова, В. Міхеєва, А. Піскунова і ін. Методика педагогічного дослідження і експерименту, обробка їх результатів викладені у роботах П. Волкова, Б. Гершунського, С. Гончаренка, I. Підласного, В. Ягупова та ін. В той же час, проблема формування професійної культури майбутніх військових лікарів в умовах російсько-української війни на сході України та пандемії COVID - 19 залишається недостатньо розробленою.

Метою даної статті $€$ визначення методики і висвітлення результатів експериментальної перевірки із формування і розвитку професійної культури майбутніх військових лікарів. Проведена експериментальна перевірка ставила на меті перевірку гіпотези дослідження щодо розвитку професійної культури, в першу чергу, свідомості військових лікарів у відношенні до виконання своїх обов'язків, шляхом створення відповідних організаційно-педагогічних умов, впровадження когнітивної направленої технології, застосуванню експліцитнопсихологічного впливу до студентів медичних закладів. 
Електронне наукове фахове видання «Адаптивне управління: теорія і практика.

Виклад основного матеріалу дослідження. Сучасний етап формування i розвитку Медичних сил Збройних Сил України в умовах військової агресії Російської Федерації, поширенням інфекційних захворювань які зростають до критичного рівня потребує належної оцінки стану і перспектив підготовки майбутніх військових лікарів в системі військово-медичної освіти, яка повинна бути інтегрована в освітній процес Європейського співтовариства та відповідати стандартам військової освіти країни НАТО.

Світова федерація медичної освіти (СФМО/ WFME) у стандартах якості післядипломної освіти визнає, що рівень підготовленості медичного працівника не повинен залежати від локальної політики будь-якої країни, а бути прозорим та визнаним на міжнародному рівні. Зона Європейської вищої освіти повинна будуватись на європейських культурних традиціях відповідальності освіти перед суспільством; на широкому і відкритому доступі до базової та післядипломної освіти; на освіті спрямованої на всебічний розвиток особистості та навчанні її впродовж всього життя.

Виникає необхідність отримання обгрунтованих наукових результатів, щодо педагогічної оцінки системи підготовки військових лікарів шляхом впровадження низки педагогічних досліджень.

3 метою вивчення окремих сторін професійної культури майбутніх військових лікарів, дослідження висунутої гіпотези щодо моделі і методики іiі розвитку постає потреба проведення педагогічного експерименту, i як результат, пошук нової сучасної технології педагогічного процесу, виявлення необхідних умов реалізації завдань щодо якісної підготовки майбутніх військових лікарів в умовах сьогодення.

Бабанський визначає поняття «педагогічний експеримент» як комплекс методів дослідження для перевірки вірогідності педагогічних гіпотез. У роботі «Проблеми підвищення ефективності педагогічних досліджень» дослідник надає методику що методу педагогічного експерименту (Бабанський, 1982: 99$100)$.

(C) Украйнська інженерно-педагогічна академія

(С) ГО «Школа адаптивного управління соціально-педагогічними системами» (C) Шпортько В. 
Електронне наукове фахове видання «Адаптивне управління: теорія і практика.

Педагогічна наука широко використовує теоретичні засади в галузі експериментальних педагогічних досліджень таких вчених як Ю. Бабанський, С. Гончаренко, О. Данилов, В. Загвязинський, Л. Занков, А. Піскунов, Н. Кузьміна i iн. С. Гончаренко надає розгорнуту форму педагогічного експерименту, який повинен спиратись на весь арсенал дослідницьких методів, що веде до нагромадження емпіричного матеріалу, забезпечує перехід від спостереження до глибокого пізнання і вироблення практичних рекомендацій (Гончаренко, 2008: 178).

Розглядаючи методику експериментальної перевірки організаційнопедагогічних умов формування професійної культури слід зазначити що метою експериментальної роботи була перевірка основних теоретичних положень дисертації, оцінювання ефективності моделі і методики формування професійної культури майбутніх військових лікарів у системі військовомедичної освіти.

На початку дослідження було складено план-програму експериментальної роботи здійснення якої була розраховано з 2017 по 2020 рік. Заданням педагогічного експерименту, було з'ясування порівняльної ефективності застосованих у педагогічній практиці методів, технологій, нових прийомів, форм роботи. В межах нашого дослідження постало завдання визначити рівень сформованості і розвитку професійної культури майбутніх лікарів в системі військово-медичної освіти. За типологією проведення експерименту, на початку дослідження було здійснено вивчення документів, наукової літератури, проблематику із станом професійної культури лікарів, в тому числі країн НАТО та ЄС (Шпортько, 2020: 389-402). Були уточнені основні поняття щодо змісту і суті професійної культури у теорії і практиці досліджень, після чого у 2018 році було проведено констатуючий експеримент (Шпортько, 2020: 32-36). Результати констатуючого експерименту дозволили встановити стан предмету дослідження, виявити рівень сформованості і розвитку професійної культури майбутніх військових лікарів на початку їх навчання у вищому медичному 
Електронне наукове фахове видання «Адаптивне управління: теорія і практика. Серія «Педагогіка»

Випуск 9(17), 2020

закладі з метою іiі подальшого розвитку і формування. Проміжний етап, контрольний експеримент (пізнавально-пошуковий), проведено у 2019 році, а формуючий експеримент завершено у 2020 році.

У проведенні констатуючого експерименту із вивченням кола питань формування і розвитку професійної культури майбутніх військових лікарів прийняли участь 220 студентів Національного медичного університету імені O.О. Богомольця та Київського медичного університету усіх основних спеціалізацій медичних напрямків навчання. У подальшому, на другому етапі експерименту, пізнавально-пошуковому, прийняли участь 430 студентів 3-4 курсів медичних університетів а також слухачі першого курсу УВМА.

На етапі формуючого експерименту, прийняли участь 110 слухачів і викладачів УВМА. 3 метою проведення експерименту безпосередньо були використані такі методи дослідження як метод незалежної експертної оцінки групою експертів, методи спостереження, бесіди, анкетування і математичної обробки інформації. На етапі проведення контрольного експерименту до нього приєднались слухачі першого курсу УВМА, які були прийняті в цей час на навчання в Українську військово-медичну академію із Вінницького, Запорізького, Одеського, Тернопільського, Івано-Франківського медичних університетів, що дало змогу охопити опитуванням представників усіх регіонів України.

В 2018 році у ході констатуючого експерименту було уточнено існуючу систему організаційно-педагогічних умов 3 формування професійної культури майбутніх військових лікарів в системі військово-медичної освіти. Стан сформованості і розвитку професійної культури майбутніх військових лікарів було вивчено шляхом визначення рівня таких компонентів професійної культури як когнітивного, комунікативного, організаційного, моральноетичного, поведінкового і етнокультурного.

Першим досліджуваним показником проведеного нами констатуючого експерименту було визначення рівня сформованості і розвитку когнітивного 
Електронне наукове фахове видання «Адаптивне управління: теорія і практика. Серія «Педагогіка"

компоненту професійної культури майбутніх військових лікарів. Результати засвідчили що низький рівень розвитку когнітивного компоненту встановлено у $32 \%$ опитуваних. У ході проміжного, контрольного експерименту, низький рівень когнітивного компоненту дорівнював 25\%, а у ході констатуючого $15 \%$.

Середній рівень розвитку когнітивного компоненту протягом констатуючому етапу експерименту показали $58 \%$ опитуваних. За результатом проміжного, контрольного експерименту, середній рівень дорівнював 60\%, а на формувальному 65\%. Про значний розвиток високого рівня когнітивного компоненту свідчить його зріст за визначеними вище етапами експерименту: 10\%, 15\%, 20\%. Звичайно, слід зазначити що велика шкала розбіжностей когнітивних показників виникає у студентів медичних закладів між групами які навчаються на бюджетній формі навчання і групами студентів що навчаються на контрактній основі. Високі показники когнітивного компоненту показали достатньо вмотивовані до навчання студенти факультету підготовки військових лікарів, у подальшому, більша частина з яких розпочала навчання в УВМА.

Комунікативна культура лікаря є вагомою частиною професійної культури i компетентності військового медика. В ході дослідження нами було встановлено, що комунікативна культура майбутнього лікаря формується на грунті мотиваційних і особистісних компонентів, прояву загальної культури, комунікативних знань та навичок. Для визначення рівня сформованості комунікативного компоненту нами були застосовано анкетування, спостереження, бесіди i інтерв’ю. Використано методику «Виявлення комунікативних здібностей» (В. Бойка), діагностику здатності до співпереживання (С. Дідато), комунікабельності особистості (тест Ряховського).

Використовувались анкети з питаннями відкритого і закритого типів, де студенти обирали альтернативну відповідь, або висловлювали свої думки. За допомогою бесід і анкетування нами ретельно було досліджено рівень набутих 
Електронне наукове фахове видання «Адаптивне управління: теорія і практика. Серія «Педагогіка»

студентами комунікативних знань, розуміння того як студенти розуміють усвідомлення потреби у підвищенні комунікативного рівня.

Показники проведення дослідження комунікативного компоненту експерименту, наведені у таблиці за етапами дослідження (у відсотках):

\begin{tabular}{|c|c|c|c|}
\hline & $\begin{array}{ll}\text { ий } & \text { Констатуюч } \\
\end{array}$ & Проміжний & $\begin{array}{ll}\text { ий } & \text { Формувальн } \\
\end{array}$ \\
\hline $\begin{array}{l}\text { Низький } \\
\text { рівень }\end{array}$ & 25 & 20 & 14 \\
\hline $\begin{array}{l}\text { Середній } \\
\text { рівень }\end{array}$ & 53 & 49 & 51 \\
\hline $\begin{array}{l}\text { Високий } \\
\text { рівень }\end{array}$ & 22 & 31 & 35 \\
\hline
\end{tabular}

Констатуючий експеримент щодо виявлення рівня сформованості комунікативного компоненту показав що низький рівень розвитку комунікаційних умінь і навичок присутній у $25 \%$ студентів, і є достатньо низьким для майбутніх військових лікарів. Середній показник комунікативного компоненту показали $53 \%$ опитуваних, високий встановлено у $22 \%$ студентів.

Серед комунікативних труднощів для студентів виявлені так як: страх аудиторії, хвилювання, нерішучість; низький рівень навичок у спілкуванні; неготовність вести діалог із викладацьким складом і студентами старших курсів. Вивчення комунікативних навичок які будуть потрібні майбутнім військовим медикам показало: неготовність їх до командно-адміністративного (керівного) стилю роботи із військовим колективом, статутної комунікації, навичок військової субординації (у ході занять із військово-спеціальної підготовки за програмою підготовки офіцерів запасу).

Досліджуючи мотиваційно-ціннісну складову професійної культури майбутніх військових лікарів у ході констатуючого експерименту ми спиратись на психологічні аспекти професійного становлення і досліджували мотиви, які спонукали особистість до обрання професії. Слід погодитись із думкою науковців О. Бодальова і О. Черних (Бодальов, Черних, 1983: 162) які дають 
Електронне наукове фахове видання «Адаптивне управління: теорія і практика. Серія «Педагогіка»

оцінку мотивів у виборі професії, серед них: матеріальна зацікавленість, прагнення зміцнити свій соціальний статус, бажання самостверджуватись та впливати на інших людей, наукові або альтруїстичні інтереси.

Нами було застосовано методику «Ціннісні орієнтації» М. Рокіча (Райгородский, 2006: 246). Студент мав проаранжувати низку цінностей притаманну професії лікаря за значимістю. Опитуваним було запропоновано розподілити ціннісні мотивації лікаря на три групи: необхідні, користі i неприпустимі. Було також запропоновано проаранжувати мотиви щодо здобуття професії лікаря, та якісного оволодіння фахом, які ми розподілили на такі групи: прагматичні (матеріальна винагорода, зарплата, інші шляхи здобуття матеріальних благ); наукові мотиви (бажання сумлінно вчитись набувати знань, навичок, вмінь, робити наукові винаходи); альтруїстичні мотиви (якісне виконання обов'язків, покращення здоров'я пацієнтів, тощо).

Узагальнення результатів дало можливість визначити рівні мотиваційноціннісної сфери майбутніх військових лікарів у перший рік навчання, які було розподілені на три рівні (низький середній, високий).

Показники проведення експерименту із дослідження мотиваційноціннісного компоненту, наведені у таблиці (у відсотках):

\begin{tabular}{|c|c|c|c|}
\hline & $\begin{array}{ll}\text { ий } & \text { Констатуюч } \\
\end{array}$ & Проміжний & $\begin{array}{ll}\text { ий } & \text { Формувальн } \\
\end{array}$ \\
\hline $\begin{array}{l}\text { Низький } \\
\text { рівень }\end{array}$ & 20 & 16 & 13 \\
\hline $\begin{array}{l}\text { Середній } \\
\text { рівень }\end{array}$ & 61 & 60 & 55 \\
\hline $\begin{array}{l}\text { Високий } \\
\text { рівень }\end{array}$ & 19 & 24 & 32 \\
\hline
\end{tabular}

Результати анкетування на етапі констатуючого дослідження показують що низький рівень мотиваційно-ціннісного компоненту мали $20 \%$ студентів, $61 \%$ - середній і тільки 19\% високий. Високий рівень розвитку готовності студента до роботи у якості лікаря обумовлений високою мотивацією у виборі 
Електронне наукове фахове видання «Адаптивне управління: теорія і практика. Серія «Педагогіка»

професії, присвятити себе завданню рятувати і лікувати людей за будь-яких обставин. Низька мотивація свідчить на те що не всі студенти самостійно прийняли свідоме рішення стати лікарем, значна частина спиралась на думку і рішення батьків. На початку дослідження при опитуванні респондентів, значна частина головним мотивом своєї навчальної діяльності вважають отримання диплому із вищою освітою лікаря, і відповідно до цього ставлення до якісного навчання знаходиться у стадії розвитку. Деякий вплив на мотиваційноціннісний компонент розвитку професійної культури відігравав фактор росту пандемії COVID -19, що понижував мотивацію окремих майбутніх лікарів працювати у сфері спеціалізації лікаря - інфекціоніста.

Велике значення у підготовці майбутніх лікарів має формування моральноетичної складової професійної культури. Л.В. Богданова визначає професійну культуру як органічний сплав кваліфікації й моральності, що функціонує на основі трудової моралі (Богданова, 1998: 388). Серед сучасних дослідників цікавими є роботи X. Мазепи (організаційно-педагогічні умови виховної роботи в медичному коледжі) (Мазепа, 2001: 20), Л. Переймибіда (розвиток деонтологічної культури учнів медичного ліцею) (Переймибіда, 2008: 21).

В ході опитування щодо аспектів морально-етичної поведінки на етапах експерименту нами було надано перелік питань 3 метою вивчення стану сформованості і розвитку професійних і етичних цінностей. Мета була не тільки продіагностувати стан сформованості а і надати молодій особі настанови щодо адекватної самооцінки, з метою зменшення таких вад як егоцентризм, цинізм, байдужість, корисливість, надати орієнтири для подальшого самовдосконалення у деонтологічній культурі.

Дослідження морально-етичного компоненту, (наведені у відсотках):

\begin{tabular}{|c|c|c|c|}
\hline & \begin{tabular}{|l} 
\\
ий
\end{tabular} & Проміжний & $\begin{array}{ll}\text { ий } & \text { Формувальн } \\
\end{array}$ \\
\hline $\begin{array}{l}\text { Низький } \\
\text { рівень }\end{array}$ & 23 & 19 & 15 \\
\hline Середній & 62 & 56 & 50 \\
\hline
\end{tabular}

(C) Украӥнська інженерно-педагогічна академія

(С ГО «Школа адаптивного управління соціально-педагогічними системами» (C) Шпортько В. 
Електронне наукове фахове видання «Адаптивне управління: теорія і практика. Серія «Педагогіка»

\begin{tabular}{|c|l|l|l|}
\hline рівень & & \\
\hline Високий 152535 рівень & & \\
\hline
\end{tabular}

За показниками опитування констатуючого експерименту свідчать що $23 \%$ студентів показали низький рівень сформованості морально-етичного компоненту професійної культури, як майбутнього лікаря, $62 \%$ середній і лише $15 \%$ високий. У ході формувального експерименту високий рівень моральноетичного компоненту збільшився до $35 \%$, середній дорівнював 50\%, низький $15 \%$.

Важливим було вивчення етнокультурного рівня студентів і його самооцінку. Питання опитування були зосереджені на визначені обізнаності і рівня набутих знань з історії України, українського війська, народних традицій, пісень. Вивчено рівень активності студентів щодо участі їх у конкурсах, фестивалях, обговоренні телевізійних і радіо передач, читанні книг, ставленні до державної мови і її використання, тощо.

Дослідження етнокультурного компоненту (у відсотках):

\begin{tabular}{|c|c|c|c|}
\hline & $\begin{array}{ll}\text { ий } & \text { Констатуюч } \\
\end{array}$ & Проміжний & ий \\
\hline $\begin{array}{l}\text { Низький } \\
\text { рівень }\end{array}$ & 30 & 20 & 15 \\
\hline $\begin{array}{l}\text { Середній } \\
\text { рівень }\end{array}$ & 55 & 52 & 45 \\
\hline $\begin{array}{l}\text { Високий } \\
\text { рівень }\end{array}$ & 15 & 28 & 40 \\
\hline
\end{tabular}

У ході констатуючого експерименту, низький рівень етнокультурного компоненту показали 30\% опитуваних, 55\% середній і 15\% високий. Аналіз показує що етнокультурне середовище значно впливає на культуру студентів. В той же час, в УВМА була спланована і проведена предметна культурологічна робота із розвитку етнокультурного напряму професійної культури, що позитивно змінило показники. На формувальному етапі експерименту високий 
Електронне наукове фахове видання «Адаптивне управління: теорія і практика. Серія «Педагогіка»

рівень вже дорівнював 40\%, і свідчить про якісне покращення показника етнокультурного рівня удвічі, низький рівень, в свою чергу зменшився вдвоє, а середній рівень залишився майже без змін.

Вивчаючи організаційний компонент ми ставили за мету з'ясувати вміння майбутнього лікаря самостійно організувати як власну роботу, так і роботу невеликої групи колег.

Дослідження організаційного компоненту, (у відсотках):

\begin{tabular}{|c|c|c|c|}
\hline & ий Констатуюч & Проміжний & ий Формувальн \\
\hline $\begin{array}{l}\text { Низький } \\
\text { рівень }\end{array}$ & 22 & 15 & 12,5 \\
\hline $\begin{array}{l}\text { Середній } \\
\text { рівень }\end{array}$ & 54 & 59 & 58 \\
\hline $\begin{array}{l}\text { Високий } \\
\text { рівень }\end{array}$ & 24 & 26 & 29,5 \\
\hline
\end{tabular}

Констатуючий експеримент: 22\% респондентів показали низький рівень організаційних навиків, що свідчить про неготовність окремих студентів працювати у команді, брати участь у масових організаційних заходах, проявляти ініціативу і лідерські якості. У 54\% респондентів визначено середній рівень організаційних навиків і тільки у $24 \%$ високий. Студенти із високим рівнем організаторських здібностей займались волонтерською роботою, активно приймали участь у громадському житті колективів, включились у роботу студентської ради, і ін. Необхідно підкреслити, що низький рівень організаційного компоненту на етапі формувального експерименту зріс удвічі.

Нами було проведено експериментальне дослідження із визначення сформованості і розвитку професійної культури майбутніх військових лікарів в системі військово-медичної освіти. Узагальнюючи результати опитування в ході констатуючого експерименту було встановлено що високий рівень мають $17,5 \%$ опитуваних студентів, низький $25,3 \%$ а середній $57,1 \%$. Було використано методи незалежних експертних оцінок, спостереження, 
Електронне наукове фахове видання «Адаптивне управління: теорія і практика. Серія «Педагогіка»

анкетування і інтерв’ю. Результати формуючого експерименту свідчать що протягом навчання у медичних університетах і в УВМА високий рівень сформованості і розвитку професійної культури виявлено у 31,9 \% опитуваних студентів, низький $14,08 \%$ а середній $54 \%$. Відбулись якісні зміни у рівнях сформованості і розвитку професійної культури майбутніх військових лікарів.

Висновки. Отримані результати проведеного експерименту дозволили нам дослідити динаміку і розвиток професійної культури майбутніх лікарів в системі військово-медичної освіти. Результати дослідження є підгрунтям для впровадження методичних рекомендацій із розвитку професійної культури майбутніх військових лікарів для науково-педагогічних працівників системи військово-медичної освіти.

Продовження роботи у напрямку покращення культури лікарів $\epsilon$ актуальним у сучасних умовах зважаючи на потребу у якісній підготовці майбутніх військових лікарів, виходячи із існуючих загроз, особливо iз епідеміологічної обстановки, зокрема розповсюдження COVID - 19. Висновки і практичні рекомендації дослідження будуть сприяти впровадженню нових методик, удосконаленню навчальних програм i застосуванню нових педагогічних технологій 3 метою підвищення загального рівня розвитку професійної культури майбутніх військових лікарів, покращенню їх знань, умінь і навичок.

\section{СПИСОК ВИКОРИСТАНИХ ДЖЕРЕЛ}

1. Бабанский Ю. К. Проблемы повышения эффективности педагогических исследований. (Дидактический аспект): монография. М.: Педагогика, 1982. 192 c.

2. Гончаренко С. У. Педагогічні дослідження: Методологічні поради молодим науковцям. Київ - Вінниця: ДОВ «Вінниця», 2008. 278 с.

3. Шпортько В. О. Проблеми формування професійної культури і компетентності майбутніх військових лікарів в медичних університетах країн 
Електронне наукове фахове видання «Адаптивне управління: теорія і практика. Серія «Педагогіка»

НАТО. Збірник наукових праць «Військова освіта», К.: НУОУ, № 2 (42), 2020. C. $389-402$.

4. Шпортько В. О. Експериментальна перевірка організаційнопедагогічних умов розвитку професійної культури майбутніх військових лікарів у системі військово-медичної освіти. Вид. Інноваційна педагогіка, № 26, Одеса, 2020. C. 32-36.

5. Бодальов А. А. Личность и общение. М.: Педагогика, 1983. 256 с.

6. Райгородский Д. Я. Практическая психодиагностика: методики и тесты. М.: 2006. 480 c.

7. Богданова Л. В. К вопросу о культуре профессионального общения. Юбилейный сб. тр. ученых. РГАФК. посв. 80-летию академии. М.:1998. 388 с.

8. Мазепа Х. П. Організаційно-педагогічні умови виховної роботи в медичному коледжі: Автореферат дис. канд. пед. наук. 2001. 20 с.

9. Переймибіда Л. В. Організаційні засади діяльності педагогічного колективу з розвитку деонтологічної культури учнів медичного ліцею: Автореферат дис. канд. пед. наук. К: 2008. 21с.

\section{REFERENCES}

1. Babanskyi U. K. Problemi povishenija efektivnosti pedagogitheskih issledovaniy. (Didaktitheskiy aspect): monographia [Problems of increasing the effectiveness of educational research]. (Didactic aspect): monograph. M.: Pedagogika. 1982. 192 p. [in Russian].

2. Goncharenko S. U. Pedagogitchni doslidjenia: Metodologitchni poradi molodim utchenim. [Pedagogical research: Methodological advice for young scientists] Kyiv - Vinnitsa: DOV «Vinnitsa», 2008. 278 p. [in Ukrainian].

3. Shportko V. O. Problemi formuvannia profesiynoi kulturi i kompetentnosti majbutnih viiskovih likariv v medicthnih universitetah krain NATO. [Problems of formation of professional culture and competence of future military 
Електронне наукове фахове видання «Адаптивне управління: теорія і практика.

doctors in medical universities of NATO countries]. Collection of scientific works «Military education». K: NUODU, № 2 (42), 2020. pp. 389-402. [in Ukrainian].

4. Shportko V. O. Eksperementalna perevirka organizatsijnopedagogitchnih umov rozvitku profesiynoi kulturi majbutnih viiskovih likariv $\mathrm{u}$ sistemi vijskovo-medithnoi osviti. [Experimental verifications organizational and pedagogical conditions of the development of professional culture of future military doctors in the system of military medical education]. Publication Innovative pedagogy, № 26. Odesa, 2020. pp 32-36 [in Ukrainian].

5. Bodaliov A. A. Litchnost i obshenie. [Personality and communication] M.:Pedagogika, 1983. 256 p. [in Russian].

6. Raigorodskyi_D. A. Praktitheskaja psihodiagnostika: methodiki i testi. [Practical psychodiagnostics: techniques and tests]. M.: 2006. 480 p. [in Russian].

7. Bogdanova L .V. K voprosu o culture profesionalnogo obshenia. Jubileiniy sb. tr. utchenih. RGAFK. Posv. 80-letiju akademii. [On the question of the culture of professional communication]. Jubilee collection of work of scientists. RGAPC. Dedicated to the 80 th anniversary of the Academy. M.: 1998. 388 p. [in Russian].

8. Mazepa H. P. Organizatsiyno-pedagogithni umovi vihovnoi roboti v medihnomu koledji: [Organizational and pedagogical conditions of educational work in the medical college]. Auhor`s abstract dis. Cand. of ped. Science. 2001. 20 p. [in Ukrainian].

9. Pereimibida L .V. Organizatsijni zasadi dijalnosti pedagogithnogo kolektivu $\mathrm{z}$ rozvitku deontologithnoi kulturi uthcniv medihnogo litseiy: [Organizational based of activity of pedagogical collective on development of deontological culture of peoples of medical lyceum]. Auhor`s abstract dis. Cand. ped. Science. K: 2008. 21p. 
VOLODYMYR SHPORTKO

Lecturer of the department of general

military disciplines

Ukrainian military medical academy

(Kyiv, Ukraine)

\section{RESULTS OF EXPERIMENTAL VERIFICATION OF ORGANIZATIONAL AND PEDAGOGICAL CONDITIONS OF DEVELOPMENT OF PROFESSIONAL CULTURE OF FUTURE MILITARY DOCTORS IN THE SYSTEM MILITARY MEDICAL EDUCATION}

The author of the article provides the methodology and result of an experimental study and development of professional culture of future military doctors in the system of military medical education. In the article the author highlights the results of the ascertaining, control and molding experiments in which took part students of medical universities who were undergoing military training at Ukrainian medical universities and Ukrainian Military Medical Academy.

An analysis of the resent research and publications of scientists that reveal the essence of the concepts of «professional culture», highlighted similar developments in the field of military medical education in Ukraine. Carrying out his own experimental verification, the author relies on the theoretical achievements of scientists who have revealed the method of «pedagogical experiment». During the pedagogical diagnostics were used such research methods as independent expert evaluation by group of experts, observation, questionnaires, and interviews.

The task of pedagogical experiment as a whole was to test the hypothesis of research of development of professional culture of doctors, by creation of the corresponding organizational and pedagogical conditions where the author provides introduction of cognitive-directed technology, application of explicitly psychological influence to medical students. In this article the author highlights the results of experiment, which is the initial in the experimental study, and allows establishing the state of the pedagogical system being studied, the real level of formation and development of professional culture of students. According to the results of 
Електронне наукове фахове видання «Адаптивне управління: теорія і практика. Серія «Педагогіка»

ascertaining experiment, causal and consequential connections of the pedagogical process are revealed, further research work is carried out, which aims to introduce new pedagogical technology in order to improve the results in teaching and educating students of medical universities and students of UMMA.

The state of formation and development of professional culture of future military doctors was studied using such structural components of professional culture as: cognitive, communicative, motivational-value, moral-ethical, ethno cultural and organizational. The conclusions of study will contribute to the search for more effective pedagogical technologies, the achievement of quality in students' knowledge, the acquisition of sufficient professional skills and abilities.

Key words: experimental verification, professional culture, development, pedagogical diagnostics, organizational and pedagogical conditions, future military doctors.

\section{ВЛАДИМИР ШПОРТЬКО}

преподаватель кафедры общевойсковых

дисциплин

Украинской военно-медицинской

академии

(Киев, Украина)

\section{АНАЛИЗ РЕЗУЛЬТАТОВ ФОРМИРУЮЩЕГО ЭКСПЕРИМЕНТА} ПО ПРОВЕРКЕ ОРГАНИЗАЦИОННО-ПЕДАГОГИЧЕСКИХ УСЛОВИЙ РАЗВИТИЯ ПРОФЕССИОНАЛЬНОЙ КУЛЬТУРЫ БУДУЩИХ ВОЕННЫХ ВРАЧЕЙ

Автором статьи предоставляется методика и результаты проведенного экспериментального исследования состояния и развития профессиональной культуры будущих военных врачей в системе военно-медицинского образования. Статья освещает результаты констатирующего, контрольного и формирующего экспериментов, в которых приняли участие студенты медицинских университетов Украины, проходили военную подготовку в 
Електронне наукове фахове видання «Адаптивне управління: теорія і практика. Серія «Педагогіка»

медицинских университетах, и слушатели Украинской военно-медицинской академии.

Приведен анализ последних исследований и публикаций ученых, раскрывающих суть понятия «профессиональная культура», освещены аналогичные разработки в области военно-медицинского образования Украины. Осуществляя свою экспериментальную проверку, автор опирается на теоретические наработки ученых, в которых раскрыта методика «педагогического эксперимента». В течение педагогической диагностики были использованы такие методы исследования как независимая экспертная оценка группой экспертов, наблюдение, анкетирование, беседа и интервью.

В течение педагогического эксперимента была поставлена задача проверку гипотезы исследования по развитию профессиональной культуры врачей, путем создания соответствующих организационно-педагогических условий, где автор предполагает внедрение когнитивно-направленной технологии, применение эксплицитно-психологического воздействия к студентам медиков. В данной статье автор осуществляет анализ результатов этапов проведения констатирующего и формирующего эксперимента,

позволяет установить состояние педагогической системы изучаемого реальный уровень сформированности и развития профессиональной культуры студентов. По результатам экспериментального исследования оказываются причинноследственные связи продолжительности педагогического процесса, происходит дальнейшая исследовательская работа, что позволяет внедрение новой педагогической технологии направленной на улучшение результатов в обучении и воспитании студентов медицинских университетов и слушателей УBMA.

Развитие профессиональной культуры будущих военных врачей в системе военно-медицинского образования были исследованы с помощью таких структурных компонентов как: когнитивного, коммуникативного, мотивационно-ценностного, морально-этического, этнокультурного и 
Електронне наукове фахове видання «Адаптивне управління: теорія і практика. Серія «Педагогіка» Випуск 9(17), 2020

организационного. Выводы исследования использованы при внедрении педагогических технологий, позволяющих в дальнейшем корректировать методику процесса обучения будущих военных врачей, продолжать поисковоэкспериментальную работу с целью улучшения форм и методов обучения студентов, приобретение ими достаточных профессиональных навыков и умений.

Ключевые слова: экспериментальная проверка, профессиональная культура, развитие, педагогическая диагностика. 